\title{
Impact of COVID -19 on MSMEs in India
}

\author{
Dr. Pradeep Kumar N
}

Assistant Professor of Commerce, Mahatma Gandhi College, Thiruvananthapuram, Kerala, India

\section{To Cite this Article}

Dr. Pradeep Kumar N, "Impact of COVID -19 on MSMEs in India", International Journal for Modern Trends in Science and Technology, Vol. 06, Issue 06, June 2020, pp.:76-79; https://doi.org/10.46501/IJMTST060617

\section{Article Info}

Received on 28-April-2020, Revised on 29-May-2020, Accepted on 02-June-2020, Published on 10-June-2020.

\section{ABSTRACT}

The Micro Small and Medium enterprises (MSMEs) have been accepted as the engine of economic growth and play an important role in the equitable economic development of country. The MSMEs constitute over 90\% of total enterprises in most of the economies and are credited with generating the highest rates of employment growth and account for a major share of industrial production and exports. Coronavirus outbreak is eroding the already battered Indian economy in more ways than one.MSMEs, which is a crucial pillar of emerging economy like India's are not able to do business as usual.The main objective of the study is to measure the major liquidity measures announced by the Central Government in this pandemic situation and to identify the rise of MSMEs in India and the initiatives by the banks. The study is based on the secondary data.

KEYWORDS: MSMEs, Covid-19, NBFCs, Liquidity

Copyright (C) 2014-2020 International Journal for Modern Trends in Science and Technology

DOI: https://doi.org/10.46501/IJMTST060617

\section{INTRODUCTION}

The Micro Small and Medium enterprises (MSMEs) have been accepted as the engine of economic growth and play an important role in the equitable economic development of country. The major advantage of the sector is its employment potential at low capital cost. The labour intensity of the MSME sector is much higher than that of the large enterprises. The MSMEs constitute over 90\% of total enterprises in most of the economies and are credited with generating the highest rates of employment growth and account for a major share of industrial production and exports.

MSMEs have been established in almost all-major sectors in the Indian industry such as Food Processing, Agricultural Inputs, Chemicals \& Pharmaceuticals, Engineering; Electricals, Electronics, Electro-medical equipment, Textiles and Garments, Leather and leather goods, Meat products, Bio-engineering, Sports goods, Plastics products, Computer Software, etc.As per available statistics (4th Census of MSME Sector), this sector employs an estimated 59.7 million persons spread over 26.1 million enterprises. It is estimated that in terms of value, MSME sector accounts for about $45 \%$ of the manufacturing output and around $40 \%$ of the total export of the country.

Corona virus outbreak is eroding the already battered Indian economy in more ways than one. Demand has nosedived. Consumer sentiments have dampened. Job scenario has worsened. Cash flows in companies are declining. The financial sector is seemed to be caught in the middle of this pandemic driven disruption. While the government and the RBI have responded with a slew of measures and off cycle rate cuts, it will be a tough road ahead for financial institutions. The going will be a tough for NBFCs. MSMEs, which is a crucial pillar of emerging economy like India's are not able 
to do business as usual. With commercial paper worth Rs 1.6 lakh crore and non-convertible debentures (NCDs) worth Rs 87000 crore coming up for redemption by June amid dwindling cash flows and banks playing hardball on extending credit ,it's a critical time for NBFCs. While RBI's Rs 1 lakh crore targeted longer term refinancing operations(TLTRO)window may benefit larger lenders, the others are likely to face a crunch.

\section{Methodology}

The main objective of the study is to measure the major liquidity measures announced by the Central Government in this pandemic situation and to identify the rise of MSMEs in India and the initiatives by the banks. The study is based on the secondary data.

\section{RESUlts AND Discussion}

The lockdown though absolutely crucial hampered both the demand and supply side of the economy. The current easing of norms will see the supply side gaining momentum, but unless demand picks up,it would do no good to the financial sector or the economy as a whole. The sectors that can immediately revive the economy are MSMEs and retail which together comprise of about 60 million units. Credit Off take in these sectors would be critical for both banks and NBFCs. Putting money in the hands of the citizens to generate demand was echoed as the most important measure that should be taken by the government. Sustaining MSMEs was also raised as being critical for the economy. Along with liquidity measures announced by the Centre and the states, KSFE, a public sector chit fund and a loan company, has also announced several schemes. It has introduced a slew of measures to help its customers including announcing loan packages for NRI coming from abroad. The Kerala State Financial Enterprises ( KSFE) reduced the rate of interest and introduced some more benefit packages for their assistance. Online auction procedure introduced in the new Chit Fund Act.

The government's decision to give a credit guarantee of 34Kcrore is enabling banks to lend more. Widening the scope of MSMEs will encourage micro enterprises to expand, which they didn't earlier due to the fear of losing concessions. There is little demand due to Covid 19 impact; even in accounts where loans have been sanctioned, with drawals have not been full.
Figure 1 shows the Growth in Credit to MSMEs by Banks.

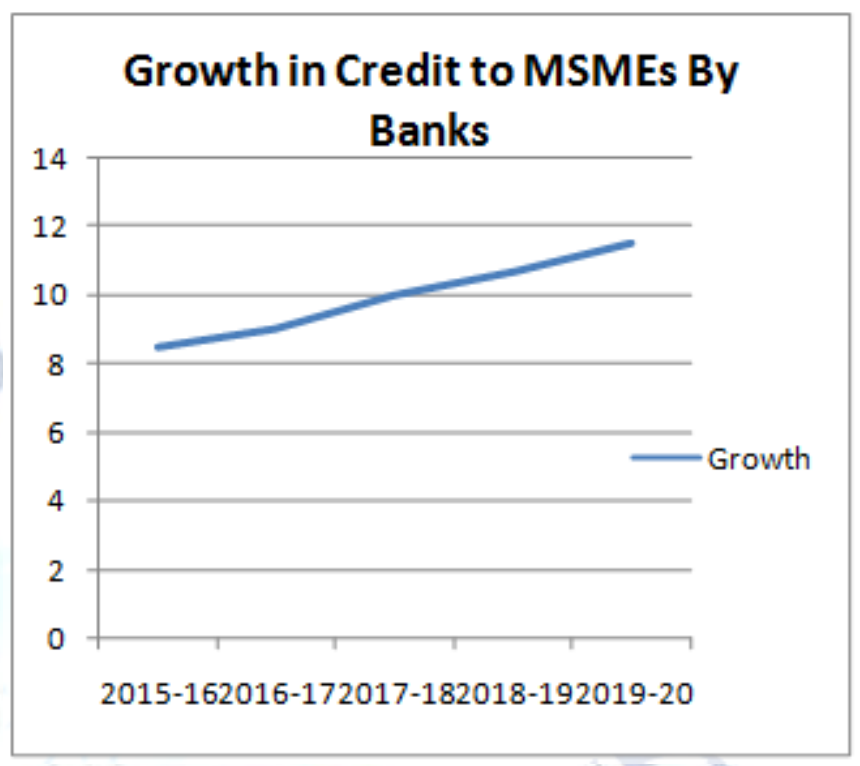

Source: RBI

Figure 2 shows the credit provided to MSMEs by Banks. Bank credit to MSMEs finally rose in January 2020 after 10 months of fall. The year on year growth was 7.7 per cent as of March 2020( RBI reports).

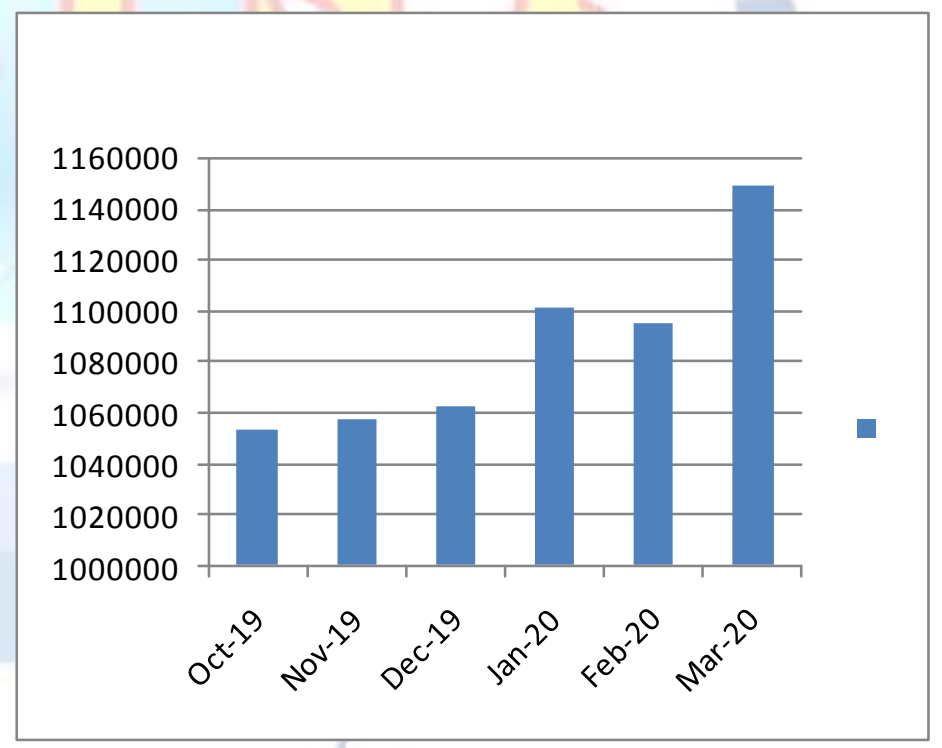

\section{Source: RBI (All figures in RsCrore)}

\section{Liquidity Measures on March 20, 2020}

Reduction of policy repo rate by 40 bps to 4 per cent

- RBI will conduct auctions of TLTRO ( Targeted Long Term Repo Operations) of up to three year tenor of appropriate sizes for a total amount up to Rs 2 Lakh crore at a floating rate, linked to policy repo rate. 
- CRR of all banks to be reduced by 100 basis points to 3 per cent beginning March 28, for one year

- MSF raised from 2 per cent of SLR to 3 per cent with immediate effect. Applicable upto June 30, 2020.

- Liquidity coverage ratio for banks reduced from 100 per cent to 80 per cent likely to release liquidity.

- Rs 50,000 crore special liquidityfacility for mutual finds.

\section{For MSMEs}

- Rs 3 lakh crore collateral free loan with 100 per cent credit guarantee.

- Rs 20,000 crore subordinate debt for stressed MSMEs.

- Rs 50,000 crore equity infusion for MSMEs with growth potential and viability through Fund of Funds.

- New definition of MSMEs-investment limit revised upwards : additional criteria of turnover introduced.

- No global tenders for government contracts up to Rs 200 crore.

- E-market linkage to be promoted as replacement of trade fairs and exhibitions

- MSME dues to be cleared within 45 days.

\section{For NBFCs}

- Rs 30,000 crore liquidity infusion for NBFCs/HFCs/MFIs

- Rs 45000 crore partial credit guarantee scheme for NBFCs

\section{For Power Utilities}

- Rs 90,000 crore liquidity infusion to DISCOMs against receivables guaranteed by State Government for clearing dues to power producers.

\section{Regulatory Measures}

- All lending institutions are being permitted to allow a moratorium of six months on repayment of instalments for term loans outstanding as on March 1,2020.

- Deferment of working capital during the moratorium period of six months will be converted into term loan repayable by March 21, 2021.

- Moratorium period to be excluded while computing 90 day NPA for asset downgrade.

- Time period allowed under RBI framework for resolution extended by 90 days $(210+90$ days $)$

\section{Financial Services ( Relaxation for 3 months)}

- Complete waiver of minimum balance charges for Savings Bank account.

- Debt card holders can withdraw cash from any bank ATM for free of charge.

- Bank charges for digital trade transactions will be reduced for all trade finance customers.

\section{Real Estate Sector and EPC/ Contractors}

- Extension of upto six months to be provided by all Central Agencies (like railways, Ministry of Road, Transport \& Highways, Central Public Works Dept. etc)

- Government agencies to partially release guarantees, to the extent contracts are partially completed.

- Registration and completion timelines extended by upto six months for all registered real estate projects.

- Concurrent extension of various statutory compliances under RERA.

\section{Insolvency and Bankruptcy Code (IBC)}

- Threshold of default under section 4 of the IBC has been increased from Rs 1 lakh to Rs 1 crore.

- Fresh admission of insolvency cases under IBC, 2016 suspended for 12 months.

- Loans of COVID-19 excluded from definition of default.

\section{Conclusion}

The green shoots of recovery of MSMEs after the Covid -19 should be sectors such as agriculture, FMCG, health, pharmacy ,transport and logistics. Also it is the good time to invest in equity markets. As the covid curve flattens across the world India's economic revival and growth would be the fastest. Good corporate governance standards, stable government and steady growth may force FIIS to flock back to India once the pandemic is over. to increase demand. More fiscal measures required to increase demand in the economy.RBI should relax NPA norms for MSMEs.

\section{REFERENCES}

[1] Ashtankar,O.M.(2007),SurvivalStrategiesforIndianSME'sin theGlobal Market, IBMRD's Journal of Management and Research, PP:77-80.

[2] Bala, N. (2007), Economic Reforms and Growth of Small Scale Industries, Deep and Deep Publications, New Delhi.

[3] Datt,R.andSundaram,K.P.M.(1999),IndianEconomy,39 ${ }^{\text {the }}$ ed ition,S.Chand and Company, New Delhi. 
[4] Dixit, A. and Pandey, A.K. (2011), 'SMEs and Economic Growth in India: Cointegration Analysis', The IUP Journal of Financial Economics,Vol.IX,No. 2, PP:.41-59.

[5] HanadiMubarak AL-Mubaraki, and Aruna, M. (2013), Technology Innovation for SME Growth: A Perception for the Emerging Economies, Journal of Economics and Sustainable Development, Vol. 4 (3), PP: 156-162.

[6] Ian Ronald Freeman, (2011) Seeking Synergy in SME financing, Southern Cross University,e-publications@SCU,Lismore,NSN.

[7] Retrieved from www.rbi.ac.in (Various Reports)

[8] Retrieved from The Economic Times, May 2020

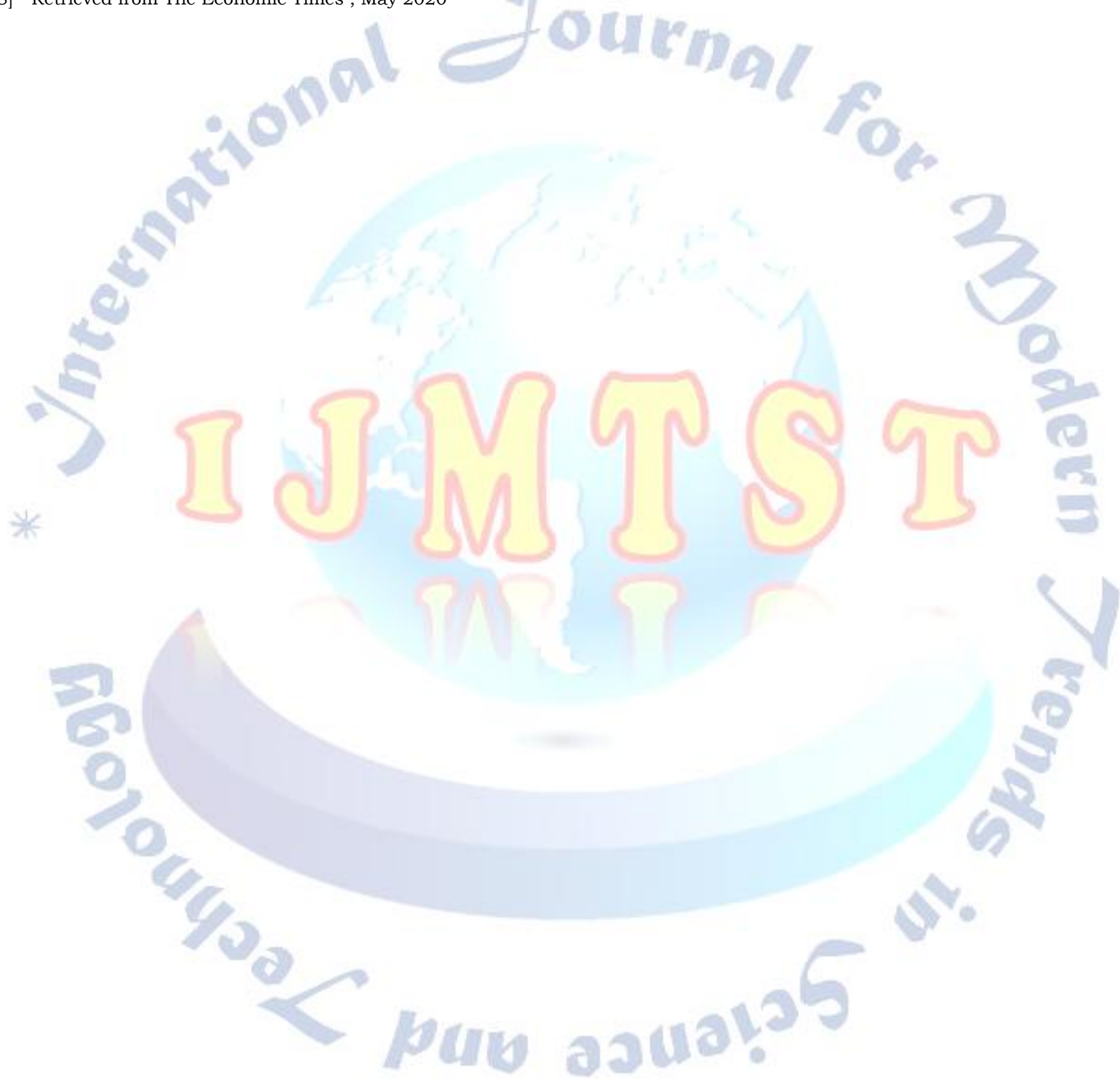

